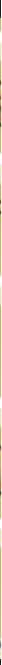

Editor:

Jaime Almansa Sánchez

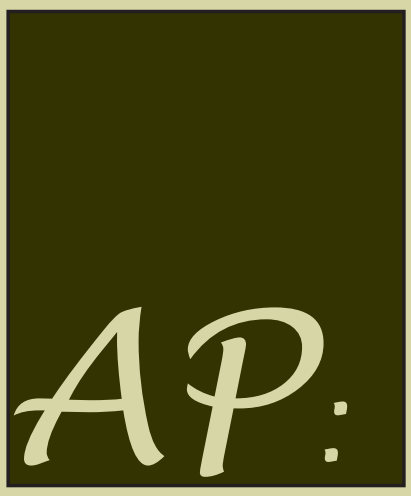

www.arqueologiapublica.es

Ontine Journat in Public Archaeology 


\title{
Public Archaeology 2.0: \\ Facilitating Engagement with Twitter
}

\author{
Nicolás R. LARACUENTE \\ University of Kentucky. Department of Anthropology
}

\begin{abstract}
Public archaeology increases public awareness of archaeological issues and their practical applications to modern social concerns. Classroom visits, hands-on activities, site tours, and otherevents give archaeologists the opportunity to engage the public and transfer knowledge through face-to-face interaction. However, engagement ends at the conclusion of the event, leaving the audience with an incomplete understanding of the subject. Twitter, a social media application, transcends these spatial and temporal limitations by allowing sustained multi-directional communication among archaeologists, their audience and others who never attended the original event. However, there are problems with assessing the success of public archaeology projects and the presentation format differs dramatically from traditional forms of publication.
\end{abstract}

\section{Key words}

Public Archaeology, Twitter, Engagement

\section{Introduction}

Archaeology is the study of human societies through their material remains. One of the main goals of public archaeology is to facilitate understanding of archaeological techniques and the results of our excavations through a variety of methods. Classroom visits, hands-on activities, site tours, and lectures provide opportunities for public engagement and education. Audiences range from children to adults, with varying skill levels and varying interests in archaeology. These events are also time-limited. They last anywhere from a few minutes to a few hours and conclude with a few interested parties who linger to ask follow-up questions. A complete understanding of the activity's message depends on the notes taken by the audience, handouts included in the event, or their memory. 
This paper argues that social media, specifically Twitter, can facilitate archaeological engagement by providing opportunities for interaction past the time limits of the original event. Employing social media effectively requires a critical understanding of the technology at hand in addition to an expert understanding of material relayed through that medium. Twitter, a social media micro-blogging application, was the focus of this research. Examining the utility of Twitter as an information communication technology (ICT) device within the context of archaeological engagement requires shifting focus from the technology itself to the behavior of the people that use it.

This paper begins with a hypothetical public archaeology event to illustrate different types of learning behavior. In the second section of this paper, Twitter is described, contextualized within similar types of communication, and the challenges that faces this mode of communication are assessed. The paper concludes with examples of how Twitter has been used by archaeologists and a discussion of the basic problems facing any archaeologist interested in using Twitter.

\section{Public Archaeology and Learning Types}

People learn in a variety ways (see Donovan et al. 2000: Chapter 2 and 3). Public archaeologists often encounter two learning types: directed and free-choice learning. Directed learning works best when the educator has control over the situation in terms of content and audience participation (Power and Robinson 2005:19,23). An example of this approach is a school field trip where students have worksheets with questions they have to answer for class. Students may ask questions that are prompted by their worksheets. The worksheets direct their attention assisting them with concentrating on the task at hand. Together, the worksheet and questions can guide audiences to the predetermined learning goals.

Individual interests guide free-choice learning. The audience's attention will wander to things that interest them (Chung et al. 2009:43). Free-choice learning audiences ask questions that are prompted by their interests. A good example of this type of situation is a museum. Usually, an audience has a choice of which exhibits are visited and how they are experienced. A visitor can read all of the labels or randomly browse. The entire exhibit can be experienced at once or over multiple trips. Learning activities designed for free-choice learning need multiple entry points or hooks to grab someone's attention and hold it long enough to transfer the lesson's content (Pearce 1990:162-163). 
Public archaeology events that focus on educational goals and learning outcomes are conscious of the enduring understandings they are meant to communicate. Enduring understandings are the big ideas that should stick with an audience even if none of the details are retained after the event's conclusion (Wiggins and McTighe 1998:10-11). Public archaeology events that occur at live excavation sites have several enduring understandings in common. The following are three enduring understandings used in classroom exercises conducted by the author, adapting lesson plans from Project Archaeology's Intrigue of the Past.

First, archaeology is destructive. Excavations essentially destroy the archaeological record. Archaeological techniques record the maximum amount of data from an excavation. They are often employed with a specific research question and excavation plan in mind (Smith et al. 1996:41). An excavation that lacks proper documentation or excavation technique destroys archaeological data. This data is gone forever and cannot be retrieved by conducting the excavation again.

Second, archaeological materials are limited. If an archaeological site is destroyed there are no second chances (Letts and Moe 2009:131). This is one reason why archaeologists test portions of sites rather than excavate a site in its entirety. If we leave a portion of the site undisturbed, future archaeologists can return to the site with new questions and different methods.

Finally, people bestow meanings on material things. This idea can be communicated with nearly every artifact that comes out of the ground. Ceramic sherds are often correlated with specific cultures. Decorative designs on pottery can reflect the identity of the potter or relay a story that is part of that society (Smith et al. 1996:95). Explaining how to distill information from an artifact assemblage assists in the transitions from viewing artifacts as garbage to viewing artifacts as potential sources of data.

Communicating these enduring understandings is feasible in a controlled setting like a classroom. However, when these issues are addressed during a live excavation, problems occur. For example, during the 2006 University of West Florida Field School, the learning goals were to communicate the three enduring understandings discussed above and convey information about the history of the site (Figure 1). Instead of a lecture, excavation tours more closely resembled controlled chaos. Common questions included: Why is she wearing socks? What are those orange things on the ground? Is that a bottle? How much is that worth? How does she know what to put on her paperwork? How 
do you make the walls so straight (Figure 2)? While these are all good questions and great teachable moments, these questions may not contribute to comprehension of the event's learning goals.
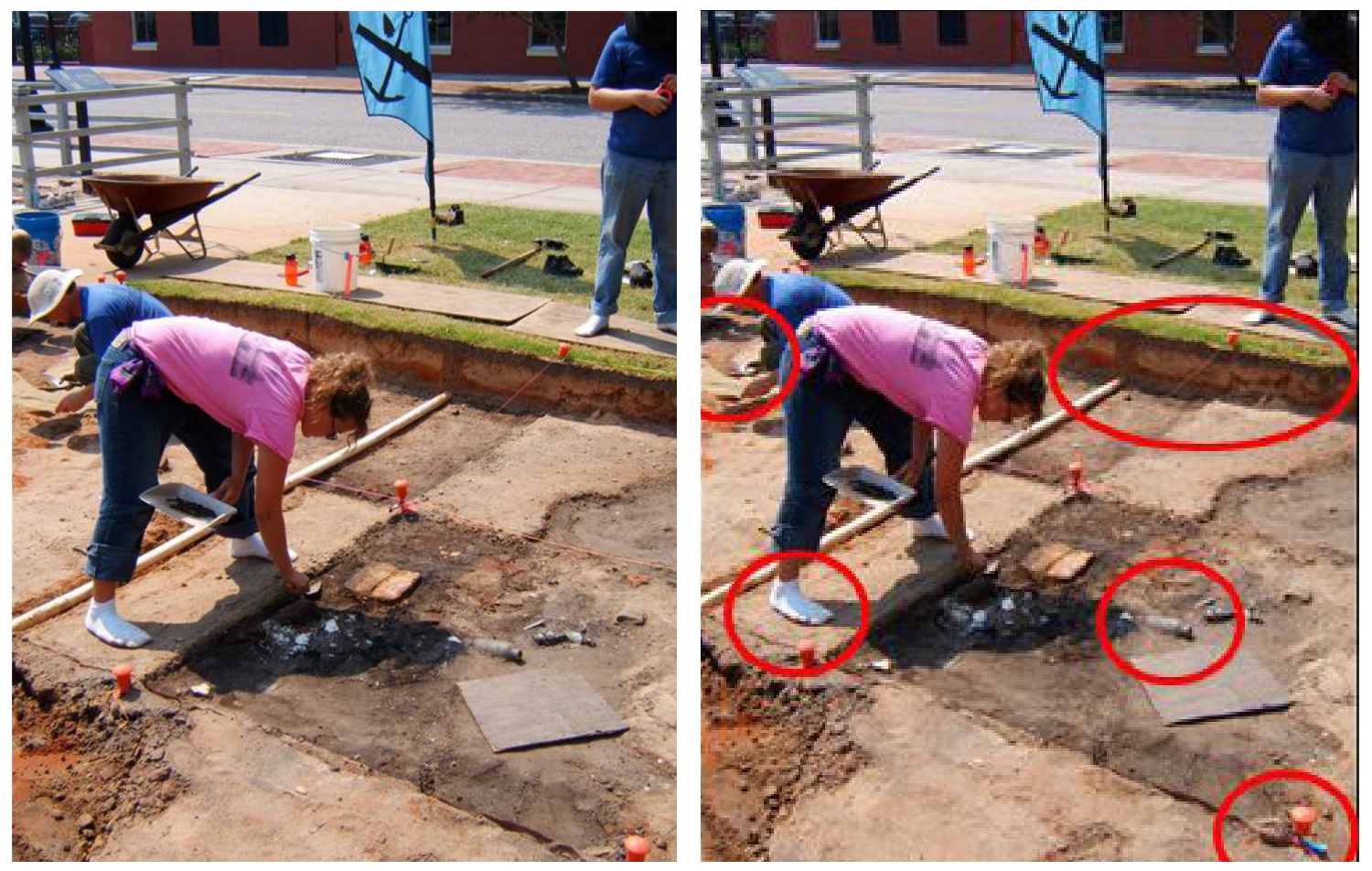

Figures 1 and 2. The excavation area during the 2006 University of West Florida Field School, Pensacola, Florida. \& Elements that distract visitors from the learning goals of an archaeology tour. Photograph by author.

This scenario demonstrates a challenge to achieving learning goals through public archaeology. In a standard classroom, a lesson plan has learning goals and a predetermined route for getting there. Distractions can be eliminated through rules against speaking or texting during class. Assigned readings prompt the topics discussed. Student seating can be arranged in a circle to promote discussion or facing forward to encourage listening to a single speaker.

An excavation site is essentially an outdoor classroom. Unlike its indoor counterpart, educators lack control of the learning environment and have to plan for a variety of learning situations and potential distractions. Public archaeologists need to plan for crowd control and safety as they guide a group of people through an excavation site. The tour content at a live excavation needs to be flexible, as the information is tied to the stratigraphic levels exposed at the time of the tour. While questions about the excavation, such as those listed above, can provide 
an effective hook to talk about excavation methodology that can lead back to an enduring understanding, there may not be enough time to address the question fully before the tour concludes. Learning can be facilitated through planning and preparation which can include a critical approach of how to engage multiple learning types.

There are multiple ways to engage free-choice learners. Social media can be a tool to engage this type of audience. This engagement must begin with a shift away from thinking of free-choice learning questions as distractions. If these questions are recognized as interest in the process of archaeology, then the barriers to learning shifts from the audience to the limited amount of interaction between audience and archaeologist. Social media applications transcend the spatial and temporal boundaries of public archaeology events by allowing sustained multi-directional communication among archaeologists, their audience and others who never attended the original event. Incorporating social media applications, such as Twitter, into public archaeology allows archaeologists to extend and sustain engagement with the audience.

\section{The Development of Twitter}

Over the past few years, social media has developed into a worldwide phenomenon. On its face, discussing archaeology through the Internet is not new. Listservs have been used to exchange information between professionals since 1986 (Hirst 2001). In the 1990's, Carol McDavid successfully engaged community stakeholders through a website that publicized the Levi Jordan Plantation excavations (McDavid 2004:50). While similar to older internet tools, social media takes advantage of a wider diversity of web platforms available, enabling information to be exchanged in multiple directions with greater speed.

In her book All a Twitter, Tee Morris traced the development of elements of the Internet that enabled the rise of Twitter. She argues that the Internet was one-sided during the 1990's. That is, Internet users were limited to moving from webpage to webpage until the development of new programming languages that enabled the creation of forums (Morris 2010:9). In 2000, Real Simple Syndication (RSS) facilitated the development of blogs by enabling Internet users to subscribe to a blogger's content. This resulted in the rise of user generated content and coincided with the development of social networking which enabled users to choose how and when they interacted, as well as the variety of media available to them (Morris 2010:10-11). 
In 2004, Odeo, a software company, was founded by Ev Williams and Biz Stone. They hired a software engineer, Jack Dorsey, and challenged him to solve a communication problem within their company (Israel 2009:16-20). Odeo employees were scattered across Silicon Valley and all worked on their own time schedules. It was difficult to find times that everyone could meet in person and nearly impossible to assess productivity. Inspired by technology used to communicate emergency vehicle routes in real-time and the availability of SMS text messaging, Dorsey created an open-source communication tool named TWTTR (Israel 2009:16, 22-25, O'Reilly and Milstein 2009:33).

TWTTR was a communication tool with viral elements. The more people that were on TWTTR, the more useful it became. As a result, TWTTR spread organically; one person used it and told another, resulting in a constantly growing pool of users (Israel 2009:133). Its popularity exploded to around 60 thousand users when Williams, Stone and Dorsey took repackaged their communications tool in a new company, Twitter Inc., and marketed it at the 2007 SXSW conference (Israel 2009: 32, 39). Several high profile events resulted in Twitter becoming firmly entrenched in the social media ecosystem.

On April 10, 2008, James Buck, a student journalist, was unjustly arrested in Egypt. He tweeted one word, "arrested", when the authorities were transporting him to the police station (Israel 2009:13 ). News of his plight traveled through a network of people connected to him via Twitter, ultimately leading to his release a few days later and a free plane ride back to the United States (Simon 2008).

On January 15, 2009, US Airways Flight 1549 landed in the Hudson River. News media rushed to cover the story, but the first picture uploaded to the Internet was not from a traditional news source. It was from Twitter. A twitter user, @JKrums, wrote, "http://twitpic. $\mathrm{com} / 135 x a$ There's a plane on the Hudson. I'm going on the ferry to pick up the people. Crazy." (Israel 2009:200).

A terrorist attack in Mumbai, India, during November 2008 prompted messages that were dispersed globally through Twitter (Comm et al. 2009:xiii). Like the Hudson River event, Twitter was used to broadcast information. It followed a pattern that caused the business writer, Joel Comm, to state that "we now live in a time where ordinary citizens are empowered to be conduits of information to the masses like never before" (Comm et al. 2009:xiv).

These conduits were displayed during global news coverage, highlighted when Oprah televised her first tweet, and manipulated 
during a well-publicized race between celebrity Ashton Kutcher and CNN to be the first to acquire 1 million followers (Comm et al. 2009:21). A 2008 survey of Twitter's users determined that $63 \%$ were male and the average age of Twitter users was 35-44. The realization that Twitter's user base was older people prompted businesses to join the service to reach potential customers in a different way (Comm et al. 2009:6). Companies, such as the computer company Dell, began providing customer service directly through Twitter (Israel 2009:47-48). This approach to customer service requires a research to prevent social media efforts from being a detriment to the company's image (O'Reilly and Milstein 2009:189).

Zoological parks have embraced the effort it takes to engage customers through Twitter. An article in Connect, a publication by the Association of Zoos and Aquariums, notes that social media is "not always free, not always easy, and not everyone who is doing it is doing it well" (Whitman 2010:8). Ciri Haugh, from the Houston Zoo, remarked that it takes constant research to stay ahead of the curve. Haugh's research determined that trivia, photos and animal facts garnered the most attention (Haugh 2010:13). Research also determined that $48 \%$ of African Americans and $47 \%$ of Hispanics accessed the Internet via mobile devices. For Houston Zoo, this makes Twitter especially effective in engaging those segments of their community (Haugh 2010:13).

\section{Using Twitter}

Twitter is a micro-blogging application that allows one to send 140 character "tweets" to their "followers". Tweets can be received via the Twitter website, third party applications, feeds embedded in websites, or text messages. Followers can respond to the original user or "retweet" the message to their followers.

It is important to realize that Twitter does not stand alone. It is a tool in the social media toolkit (Israel 2009:8).

As part of a technological tool kit, Twitter has to be used in conjunction with other technologies. With the rapid growth of technologies in the "Web 2.0" environment, it may not be possible to understand each element of social media. Some writers argue that Twitter should be used as a facilitator that directs attention between different social media elements (Morris 2000:15). Others view Twitter as a chance to distribute ideas and comments about individual interest and expertise (O'Reilly and Milstein 2009:11). Several entrepreneurs 
approach Twitter as a chance to check public opinion of their products and ideas (Israel 2009:50). While Twitter may seem like a new way to communicate, the circumstances of its development and patterns of its use are similar to that of the telegraph.

Both Twitter and the telegraph built on existing infrastructure. Telegraph lines were installed along railroad lines (Carey 1989:203). After its implementation, the telegraph allowed communication that improved the railroad's operation through prevention of train collisions. Twitter was operationalized using the existing cellular phone and Internet infrastructure. It has improved communication by removing barriers by allowing people to bypass secondary sources with a direct link to primary sources (Israel 2009:66-68). For example, at the 2010 Modern Language Association Convention in Philadelphia, the organization's executive director, Rosemary Feal, invited her twitter followers to an exclusive event. Her Twitter followers, mostly graduate students or recently minted PhDs, would have never heard of this normally private meeting with elite social leaders, supporters, and financial donors to the institution (Golden 2010).

The widespread use of Twitter prompted criticisms of the technology's 'trivialization' of the English language (Golden 2010). Ironically, the same issue confronted the telegraph. The translation of written language into dots and dashes, initially used to play long-distance chess, was criticized by Henry David Thoreau as 'trivialization' of the English language, but his criticisms were drowned out by those who embraced its potential (Carey 1989:202-203). Ernest Hemingway cited the telegraph as a major influence on his attempts to "pare his prose to the bone" (Carey 1989:211). The broad reach of the telegraph also resulted in the objectification of the news in order to be palatable to people of every political type (Carey 1989:210).

Unlike the telegraph, Twitter's structure does not automatically result in objectification of information. Indeed, it can result in the exact opposite. Twitter users do not have to follow each other to see the information. This publically accessible, asymmetrical model has two implications: 1. Twitter users are more likely to find information by strangers 2. People will unfollow you if you are not interesting (O'Reilly and Milstein 2009:7, 25). The realization that users can selectively follow who they are interest in results in the creation of social 'islands' where everyone is of the same mindset. The opt-in nature of Twitter is a vivid contrast to the required participation of the telegraph. Instead of a movement toward objectivity, it is increasingly easy to find subjective information portrayed as fact. 
The 140-character limit of tweets forces an author to strip a message to its bare essentials. The size of this chunk of information moves quickly and is distributed through a variety of channels (Levinson 2009:134). As the number of accounts a user follows increases, the amount of tweets the author sees increases exponentially, resulting in an information overload. When "people treat [Twitter] as a river of messages, dipping in when they happen to be next to the stream", information contained in a tweet may lose its context, or worse, they may not see it at all (O'Reilly and Milstein 2009:155, 165). This is a reality of working with social media, users devise multiple ways for effectively sifting through this data (Peneberg 2010:76). Understanding the structure of Twitter as a social media tool is only part of a critical approach. There has been some research toward understanding the behavior of the people who use these tools as well.

According to Whitman these social media user behaviors can be classified in six types (Whitman 2010:9):

1. Creator: submits photos and other content

2. Critic: leaves comments

3. Collector: Retweets, Social Bookmarks, RSS Feeds

4. Joiner: becomes a fan on Facebook, follower on Twitter

5. Spectator: reads blogs, watches YouTube videos

6. Inactive: No social media use.

These behaviors constantly vary or occur simultaneously, which prompts a dynamic approach to social media when engaging these communities. Whitman and others encourage an approach to Twitter where the user consciously chooses their approach and adapts it based on feedback from measurement of web traffic (Whitman 2010:9). If this approach is used in conjunction with a critical approach to public archaeology, the audience and quality of engagement can be increased.

Public archaeologists that participate in social media would benefit from an approach informed by the issues discussed above. Information presented through Twitter needs to be distilled in a different manner than work published in an academic journal or newspaper articles. The following section provides some examples of archaeologists using Twitter to relay information on publications, excavations and other archaeological events. 


\section{Examples of "Public Archaeology 2.0"}

It is impossible to describe all of the examples of how Twitter could be used in archaeology in a single paper. In this section, three examples demonstrate how Twitter amplifies and supplements public archaeology. A fourth example demonstrates how Twitter can be used as an organizing tool to facilitate large events. The section concludes with a brief discussion of how individuals with an interest in archaeology use Twitter.

To illustrate amplification, the author traced the impact of his poster for the 2010 Southeastern Archaeological Conference in Lexington, Kentucky. The Monday before the conference he uploaded a poster, titled "The Archaeology of Kentucky Bourbon", to a document-sharing site and posted the link on Twitter. Within a few hours, 3011 twitter accounts had received his tweet either directly or through followers in his Twitter network. This exposure resulted in 145 views of his poster by people who did not attend the conference (Figure 3 ).

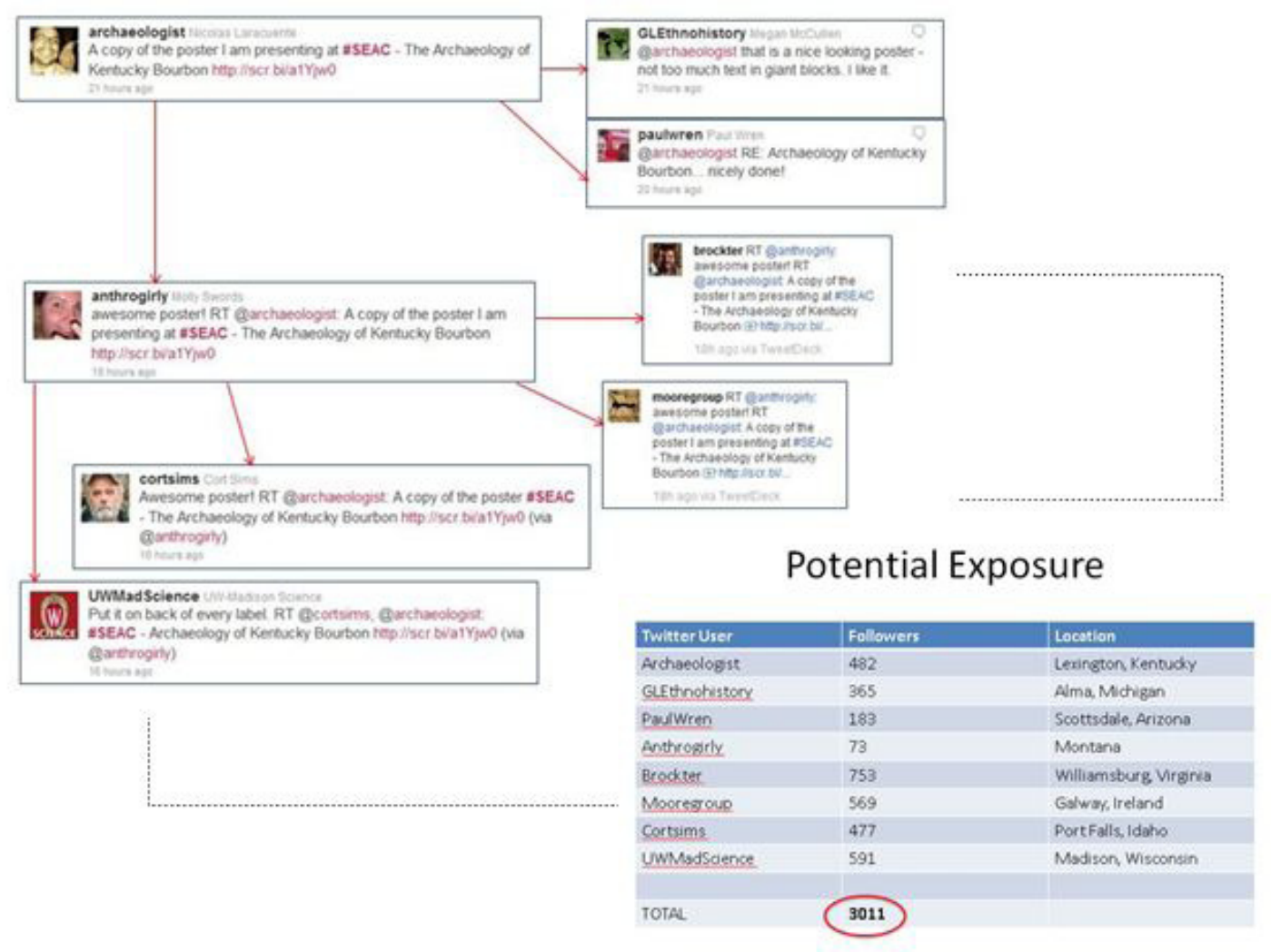

Figure 3. Tracking the amplification of the author's conference poster. 
By engaging a subset of Twitter users, his poster reached a group of communities that was diverse both in geographic location and interests. It also created an opportunity to speak with a Bluegrass native living in England. He learned that she was frustrated with the lack of Kentucky heritage taught in state schools and was concerned with preservation of the Bluegrass. She sent a copy of this poster to her family in Lexington. Despite the long route, his work reached members of Bluegrass communities that had not been accessed through traditional methods.

However, this exercise demonstrates only the potential impact of a single tweet. The impact was measured in hits on a webpage, not comprehension. Public archaeologists concerned with engaging audiences to achieve learning goals need to use Twitter as a hook to facilitate conversation. In the example above, the author achieved this level of engagement with only one of the many accounts that received the original tweet. Tailoring a social media approach to target a specific audience increases the comprehension of material, while excavations that occur in the same area provide an opportunity to increase the impact of social media.

The Campus Archaeology Program at Michigan State University engages the University community with a multifaceted social media program. The program's webpage (http://campusarch.msu.edu/) integrates a twitter feed, Youtube content, and the Campus Archaeology Program Blog, in addition to directing website visitors to Flickr and Facebook (Figure 4). From the website visitors learn that the program's mission is to protect their university's cultural resources during campus

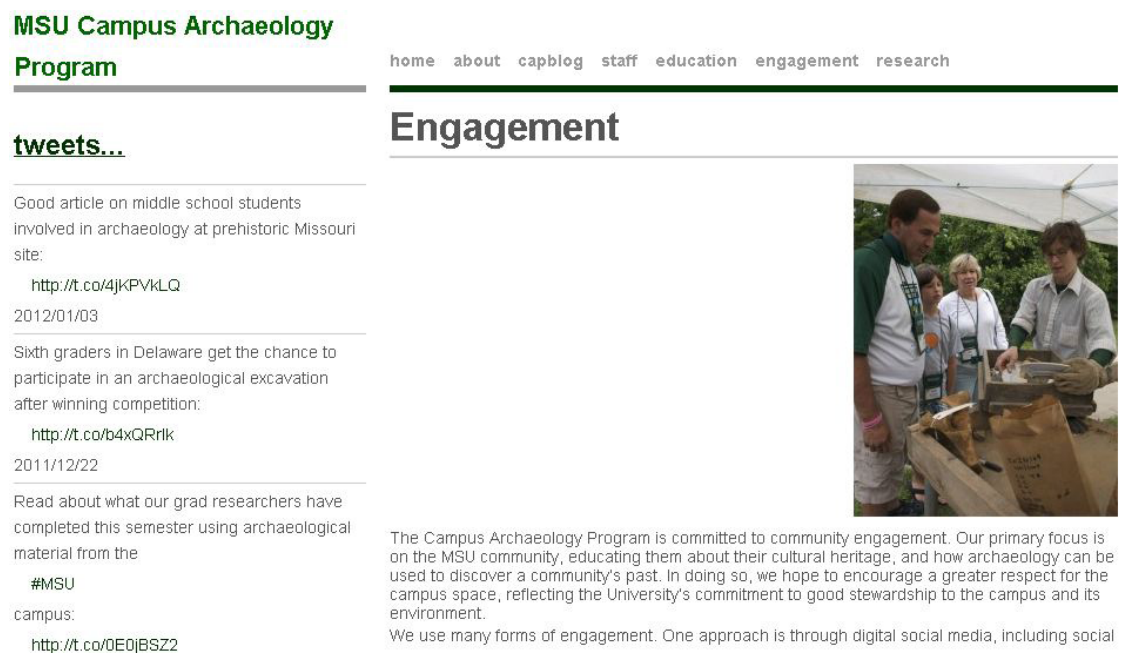

Figure 4. The Campus Archaeology Program's webpage 
construction (Campus Archaeology Program, accessed January 2012). Visitors also have information on the program's staff and access to research published as result of their excavations.

Twitter plays a role of redirecting people to related content on the Campus Archaeology Program's Facebook page or blog; they also "live tweet" their excavations. Tweets and photos posted from the field can attract people to excavations as they are happening (Figure 5). It can also facilitate the understanding of the program's work for people who cannot physically visit the excavations. The Campus Archaeology Program's use of social media is mainly a supplement to face-to-face community engagement. However, the information is also accessible by a global audience whose only reason for following the Campus Archaeology Program's Twitter account is an interest in archaeology. The tweets visible on their webpage in Figure 4 provide links to archaeologically related material in Missouri and Delaware. While these are not related to the Campus Archaeology Program's main mission, they provide content that engages people interested in archaeology in general.

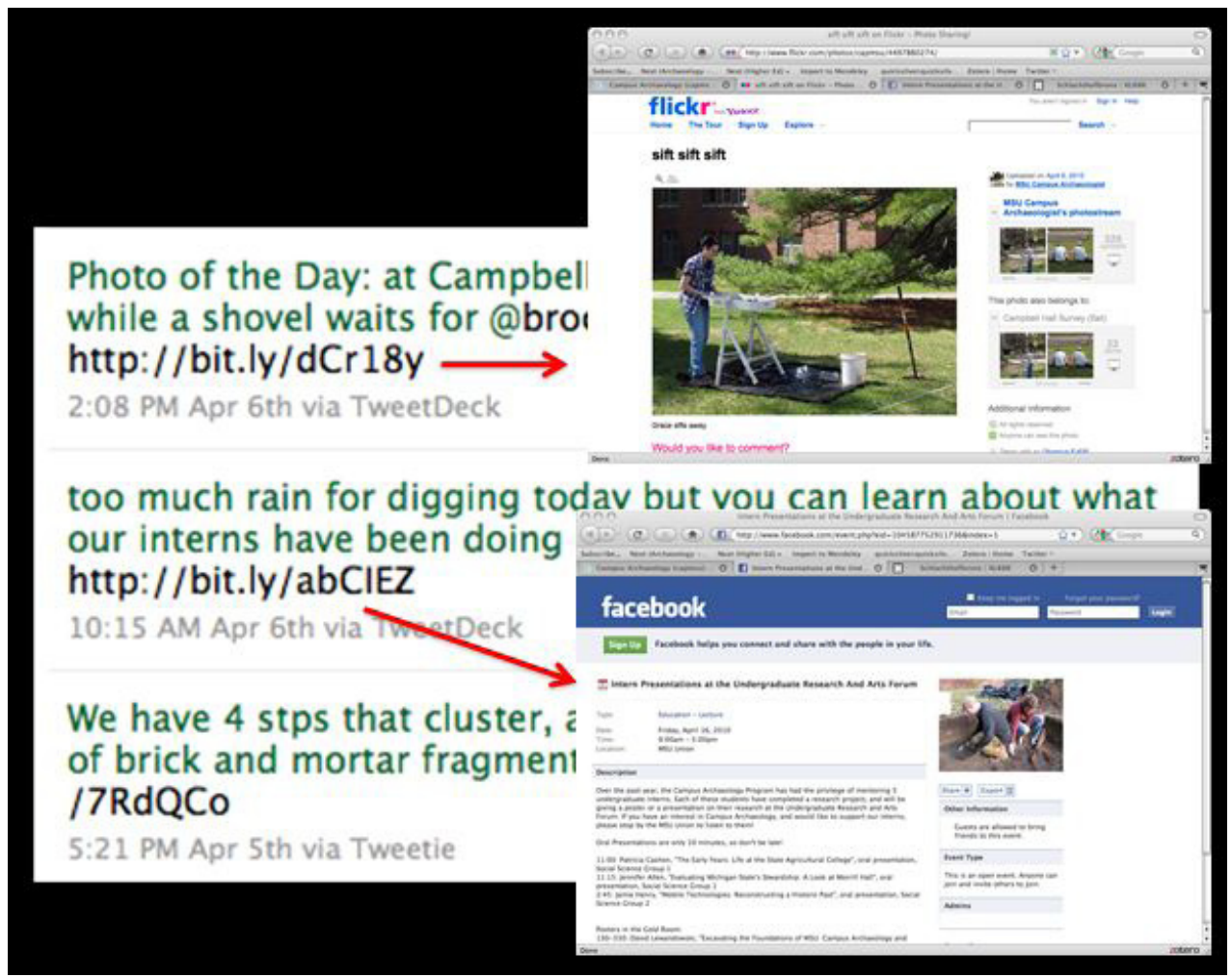

Figure 5.

The Campus Archaeology Program using Twitter for 'live tweeting' excavations. 
The Florida Public Archaeology Network (FPAN) has taken the consistent engagement provided by The Campus Archaeology Program and amplified it to the state level. Their mission statement, "to promote and facilitate the conservation, study and public understanding of Florida's archaeological heritage through regional centers, each of which has its own website", illustrates the complexity generated from this amplification (Florida Public Archaeology Network, accessed January 2012). The FPAN web presence (http://www.flpublicarchaeology.org/) is split into eight geographic regions (Figure 6) that correspond with their physical offices. Each webpage displays that region's events and information about the cultural resources of that region. Half of the regions have blogs on their web page, but not all of the blogs are updated consistently. The twitter feed for each region is integrated into the bottom right of each of the regions' web pages.

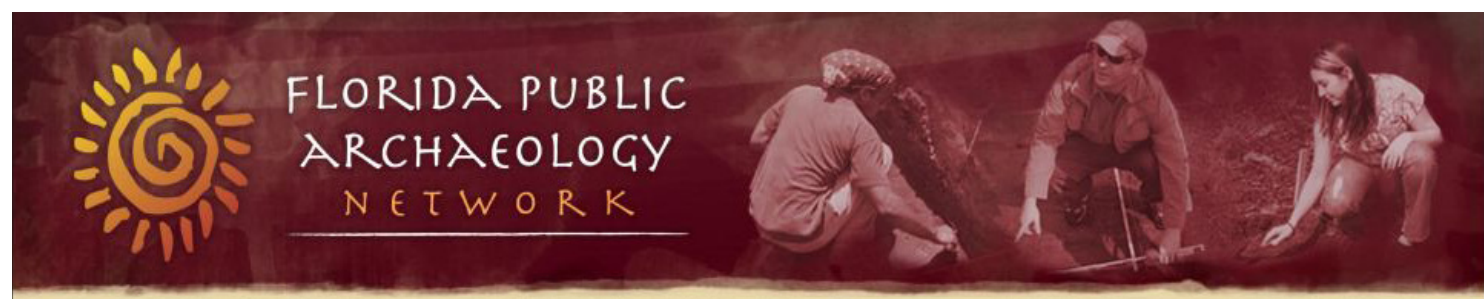

EPAN Home | Northwest | North Central | Northeast | Central | West Central | East Central | Southwest | Southeast

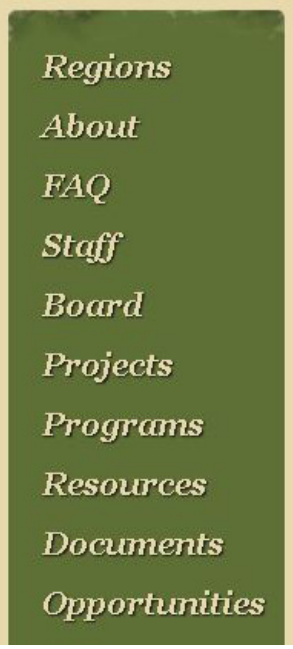

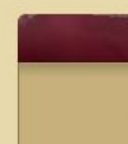

$$
\text { FPAN Statement on Anthropology in State Universities }
$$

FPAN FY 2010/2011 Annual Report Now Available

The Florida Public Archaeology Network's mission is to promote and facilitate the conservation, study and public understanding of Florida's archaeological heritage through regional centers, each of which has its own website. To learn more about a region and to visit their site, have a look at our region map or choose a location from the list of regions above.

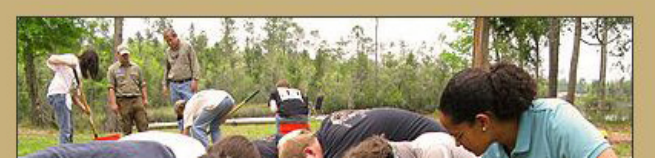

Upeoming Events

Jan,17@10:00 am in the

Northwest Region Archaeologu Lab Volunteer Dau

Jan,17@7:00 pm in the Northeast Region Lecture: Politics, Murder, \& Marturdom

Jan,18@10:00 am in the

Northwest Region

Archaeologu Lab Volunteer Dau

Jan, 18@ 7:00 pm in the

Semthwest Region Pineiand's Shell Mound's as Records of Environmental Change

Jan,19@ 5:00 pmin the

North Central Region Anhaica Apalachee and de Sotos

Figure 6. The Florida Public Archaeology Network Webpage 
To facilitate interaction with their local communities, the FPAN twitter accounts reflect their geographic region (i.e. @FPANSouthEast). Like the Campus Archaeology Program, FPAN uses these accounts to provide live tweets from wherever FPAN archaeologists are working. The Northeast region (@FPANNorthEast) encourages public interaction through "What is it Wednesdays" where a picture of an artifact is displayed on the blog for visitors to identify. A link to the blog is posted on Twitter, which is often retweeted by the other FPAN regional accounts. Twitter facilitates interaction between regions as events that may be of interest in other areas of Florida are publicized through various geographic regions (Figure 7).

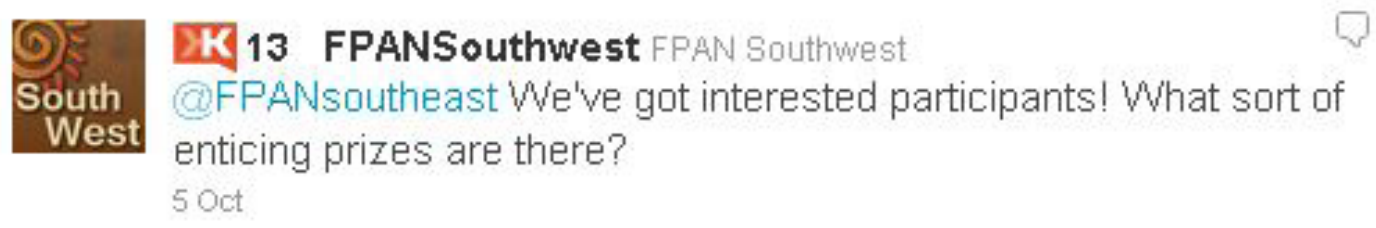

Figure 7. Using Twitter to Coordinate between the FPAN Regions

Twitter can be used on an individual level as an organizing tool among public archaeologists, as demonstrated during the Day of Archaeology 2011. This project was inspired by a conversation on Twitter between two of the organizers, Lorna Richardson (PhD Student, Centre for Digital Humanities at University College London Department of Information Studies) and Matt Law (PhD Student, Cardiff University / C \& N Hollinrake Ltd.), during the Day of Digital Humanities in March 2011. The team grew to seven organizers, three advisors and four sponsoring organizations. The premise was simple. Archaeologists, broadly defined as "everyone working or volunteering in any aspect of archaeology from anywhere in the world -- and even those who have defected", registered with the organizers and shared what they did on the Day of Archaeology, July 29th, 2011 (Day of Archaeology, accessed January 2012). Participants documented their day through photographs, video and blog posts that were proofed by the organizers and posted at http://www.dayofarchaeology.com/. By July 31st, the website was approaching 400 blog entries from across the world. Using Twitter allowed organizers to communicate efficiently on a global scale and the project results disseminated through Twitter and other social media outlets. 
Individual use of Twitter varies and most of the time Twitter is not used in association with a project or institution. Personal notes or reflections on conference presentations has been an increasingly popular use of Twitter. Archaeology related issues can be rapidly shared by topic through the use of hashtags (i.e. \#pubarch) that allow a twitter steam to be filtered removing anything that does not contain those keywords. The use of conference hashtags (i.e. \#SHA2012) allows conversations about conference topics to occur in a backchannel during presentations or while people are traveling. Relationships that are established on Twitter can facilitate the spread of archaeology-related news, projects or job openings through archaeology social media networks.

\section{Discussion - Incorporating Twitter into Archaeology}

While there is no single right way to use Twitter, some approaches are better than others. The first step would be to develop a plan for engagement through social media. Public archaeologists that decide to implement Twitter into their projects need to realize that one-way communication will not result in success:

"Twitter isn't so much a broadcast medium as it is a discussion channel... the secret of social media is that it's not about you... It's about how you can add value to the communities that happen to include you" (O'Reilly and Milstein 2009:101).

Just like the end user who identifies with several social media behaviors, archaeologists need to move among the six social media behaviors in order to maintain the interest of a diverse audience. To combat the information overflow present in a Twitter stream, they may want to repeat their own messages throughout the day. This will also engage a global audience who may be sleeping during the times public archaeologists typically use Twitter. Public archaeologists on Twitter will also have to be increasingly self-critical. For example, after building a community of followers interested in archaeology, beginning to tweet about a personal interest in dinosaurs would support the misconception that archaeologists study dinosaurs.

Approaching Twitter accounts as personal accounts versus individual accounts assists in determining the content that will be distributed through that account. The Campus Archaeology Program and the Florida Public Archaeology Network are examples of institutional accounts. Both institutions have distinct mission goals posted on their websites that guide the content relayed through their social media 
presence. To avoid simply broadcasting material, an institutional account must be used in such a way that those conversations reflect the view of the institution instead of the opinions of the individual. It is also important to be clear whether an account represents an institution or an individual. This can be can be accomplished through the account's Twitter handle.

Accounts such as @brockter or @vcwestmont are essentially modifications of a user's name. Followers of these accounts would expect to see tweets about that individual's life and interests. Those tweets intersect with their identities as archaeologists as they post pictures from the field, the lab, or share drafts of conference presentations. Accounts such as @SAAorg or @SHA_org are institutional accounts, as denoted by the suffix "-org". In general, institutional accounts are usually associated with organizations or publications. As a result, the topics they cover may be more limited to certain themes or be subject to institutional guidelines. Institutions need to be aware that tweets through these accounts can be taken as an official position or commentary on a subject.

While Twitter is primarily used as a tool for immediate conversations, curation and organization of tweets is possible. Social media tools, such as Storify (www.storify.com), allow the preservation and organization of content disseminated through nearly anywhere on the web. A single tweet can be curated with context by including associated web materials within a "story" on Storify. These curated files can be used to assess social media approaches in order to tweak future projects. They can also be used to gather materials, presented in a variety of formats at different locations on the web, in a centralized location, providing a strong foundation for beginning, or continuing, an informed discussion about any subject.

By including Twitter as a part of the project, engagement can take place at anytime among people in any location. Publicizing Twitter accounts in a variety of ways can result in a diverse audience that remains engaged long after a traditional event would have ended. Perhaps the biggest hurdle to overcome is the idea of creating a single program that requires little maintenance. Communication through Twitter flows both ways, which means that both the educator and the audience are engaged in learning. Through assessment and modification, public archaeology programs should become dynamic constructs, capable of engaging a variety of social media behaviors, learning types and content to broaden their impact past traditional techniques. 


\section{Conclusions - Potential and Problems}

Twitter may serve as a foundation for beginning public archaeology through social media. It serves as an easy entry point for archaeology experts that may not be accustomed to social media. Facebook, MySpace and similar sites can be time-intensive. There are many options for ways to interact with your friends and the accounts can be high maintenance. Twitter has three fundamental options: follow, not follow, and block (Morris 2010:22-23). The asymmetrical nature of Twitter gives a user the option to reply. A 140-character message can link people with photos and materials on any other site on the Internet.

By default, Twitter accounts are viewable by anyone with internet access. The very public nature of this social media platform means that any tweet posted to archaeology twitter accounts could spark learning opportunities for public archaeology. Individual accounts associated with archaeology students reflect the rigor of archaeology research and the challenges they face while balancing study, fieldwork and personal lives. Institutional accounts can reflect the effort of organizing a conference, link users to forums that summarize current controversies, or advertise events that are open to the public. Incorporating Twitter in all phases of a project allows interested members of the public to learn about all stages of the archaeological process, from fieldwork to publication.

A potential problem with people engaging with archaeology through Twitter is the way in which the interested public accesses these materials. After creating an account, a new Twitter user could search using the Twitter hashtags such as \#archaeology, \#artifacts, or \#history. This would result in every tweet that included those hashtags, regardless of if the linked material is pseudo-archaeology, inaccurately reported archaeology, or other problematic material. Maintaining an active community of professional archaeologists, who actively engage with problematic materials and the people who access them, opens a dialogue that may not have otherwise occurred. However, the volume of material shared through Twitter precludes this community from addressing all problematic materials. Getting involved with Twitter, or supporting those who are already involved, will ensure that these much needed dialogues continue to occur. 
Nicolas R. LARACUENTE - Public Archaeology 2.0: Facilitating Engagement... - 98

\section{Bibliography}

Carey, J.W. 1989. Technology and Ideology: The Case of the Telegraph. In Communication as Culture: Essays on Media and Society, 201-230. Winchester, Unwin Hyman.

Chung, J., Wilkening, S. and Johnstone, S. 2009. Coming Soon: The Future, The Shape of Museums to Come. Museum, MayJune.

Comm, J., Robbins, A. and Burge, K. 2009. Twitter Power: How to Dominate Your Market One Tweet at a Time. Wiley.

Donovan, M.S., Bransford, J.D. and Pellegrino, J.W. (eds.) 2000. How People Learn: Bridging Research and Practice. National Research Council.

Golden, S. 2010. Tweetup at the MLA. Inside Higher Ed, January 4, 2010. Retrieved on 17th February 2012 from www [http:// www.insidehighered.com/news/2010/01/04/tweeps]

Haugh, C. 2010. Right Back at You. Connect Feb 2010, 12-13.

Hirst, K. 2001. Articulations: Chatting with Archaeologists, March 11th Chat: Anita Cohen-Williams. Retrieved on 17th January 2012 from www [http://archaeology.about.com/library/chat/ blchatcohenwilliams.htm]

Israel, S. 2009. Twitterville: How Business Can Thrive in the New Global Neighborhoods. New York, Penguin.

Letts, C.A. and Moe, J.M. 2009 Project Archaeology: Investigating Shelter. Montana State University.

Levinson, P. 2009. New Media. Boston, Allyn \& Bacon.

McDavid, C. 2004. From "Traditional" Archaeology to Public Archaeology to Community Action: The Levi Jordan Plantation Project. In P. Schackel and E. Chambers (eds.) Places in Mind: Archaeology as Applied Anthropology. New York, Routledge, 35-56. 
Morris, T. 2009. All a Twitter: A Personal and Professional Guide to Social Networking with Twitter. Que.

O'Reilly, T. and Milstein, S. 2009. The Twitter Book. O'Reilly Media.

Pearce, S.M. 1990. Archaeological Curatorship. Smithsonian Institution Press.

Peneberg, A.L. 2009. Viral Loop: The Power of Pass-it-on. Hyperion Books.

Power, L. and Robinson, J.P. 2005. Exhibit Development with School in Mind. Journal of Museum Education, Spring/Fall.

Simon, Mallory 2008. Student 'Twitters' his way out of Egyptian jail. CNN April 25, 2008. Retrieved on 17th January 2012 from [http://www.cnn.com/2008/TECH/04/25/twitter.buck/]

Smith, S.J., Moe, J.M., Letts, K.A. and Paterson D.M. 1996. Intrigue of the Past: A Teacher's Activity Guide for Fourth through Seventh Grades. United States Department of the Interior, Bureau of Land Management.

Whitman, R. 2010. Finding Your Place in Social Media. Connect Feb 2010, pp 8-9.

Wiggins, G. and McTighe, J. 1998. Understanding by Design. Association for Supervision and Curriculum Development. 


\section{AP: Ontine Journat in Public Archaeology}

Editor:

Jaime Almansa Sánchez

Email: almansasanchez@gmail.com

Assistant editor:

Elena Papagiannopoulou

Edited by:

JAS Arqueología S.L.U.

Website: www.jasarqueologia.es

Email: jasarqueologia@gmail.com

Address: Plaza de Arteijo 8, T-2, 28029 - Madrid (Spain)

--

Cover Image: Storyboard for a PSA in Philly (H. Winograd and M. Haas)

Copyright (C) 2012 JAS Arqueología S.L.U. (edition) \& Authors (content)

ISSN: 2171-6315

Quotation:

Laracuente, N. 2012. Public Archaeology 2.0: Facilitating engagement with Twitter. AP Journal Vol. 2, 81-99.

AP Journal is a peer-reviewed journal devoted exclusively to Public Archaeology. It is freely distributed online on the Website:

www.arqueologiapublica.es

You can also follow us on:

Blogger:

= http://arqueologiapublica.blogspot.com/

Twitter:

http://twitter.com/APjournal

Facebook:

http://www.facebook.com/APJournal 